\title{
Growth and Instability in Area, Production and Yield of Onion in India
}

\author{
A. R. Nalegaonkar ${ }^{1}$, S. S. More ${ }^{2}$, R. D. Shelke ${ }^{1 *}$ and P. A. Gade ${ }^{1}$ \\ ${ }^{1}$ Department of Agricultural Economics, College of Agricultural, Latur, India \\ ${ }^{2}$ Department of Agricultural Economics, College of Agricultural, Parbhani, India \\ *Corresponding author
}

\section{A B S T R A C T}

\begin{tabular}{l}
\hline K e y w or d s \\
$\begin{array}{l}\text { Onion, Growth and } \\
\text { Instability, Area, } \\
\text { production and } \\
\text { yield }\end{array}$ \\
\hline Article Info \\
\hline $\begin{array}{l}\text { Accepted: } \\
\text { 20 October } 2020 \\
\text { Available Online: } \\
10 \text { November } 2020\end{array}$ \\
\hline
\end{tabular}

Onion (Allium cepa) also known as bulb onion or common onion, is a vegetable crop that belongs to family Amaryllidaceae and the most widely cultivated species of genus Allium. Onion is an important horticultural commodity grown worldwide for their culinary purposes and medicinal values. Indian onions are famous for their pungency and are available round the year. One cup of chopped onion contains approximately 64 calories, $15 \mathrm{gm}$ of carbohydrate, $0 \mathrm{gm}$ of fat, $0 \mathrm{gm}$ of sugar, $2 \mathrm{gm}$ of protein and 10 percent or more of the daily value for vitamin c, vit-B-6. For the present study the growth rate and instability in area production and yield were studied for the country as a whole. The data related to area, production and productivity of onion were collected for the period 1995-96 to 2018-19. To estimate the growth in area, production and yield compound growth rate were used. Cuddy-Della Valle Instability Index was used to estimate the instability in area, production, yield. The results revels that, compound growth rate of area, production and yield of Onion were statistically significant and positive. The highest instability was observed in production of onion followed by area and yield.

\section{Introduction}

Onion (Allium cepa) also known as bulb onion or common onion, is a vegetable crop that belongs to family Amaryllidaceae and the most widely cultivated species of genus Allium. The origin of the onion is central Asia and West Pakistan. Onions were grown in India and China 5000 years ago. It probably acquired its name from the city built by ONIA in 1703 B.C. near gulf of Swez. In India onion has been grown from ancient times as mentioned in a famous early medicine treatise charaka Samhita (6 B.C.). Today Onion continue to be an important part of our diet. Onion is an important horticultural commodity grown worldwide for their culinary purposes and medicinal values. Indian onions are famous for their pungency and are available round the year. One cup of chopped onion contains approximately 64 calories, $15 \mathrm{gm}$ of carbohydrate, $0 \mathrm{gm}$ of fat, 0 $\mathrm{gm}$ of sugar, $2 \mathrm{gm}$ of protein and 10 percent or more of the daily value for vitamin c, vit-B-6. Onion contains antioxidants and compounds that fight inflammation decrease triglycerides and reduce cholesterol levels- all of which may lower heart disease risk. Their potent 
anti- inflammatory properties may also help reduce high blood pressure and protect against blood clots. Anthocyanin have been found to protect against certain types of cancer and diabetes. Onions are a rich source of prebiotics which help to boost digestive health, improve bacterial balance in your gut.

During 2016-17, World's total area under onion cultivation was 4.96 (million $\mathrm{Ha}$ ), total production 93.17(million tonnes) and productivity was $18.80 \quad(\mathrm{~T} / \mathrm{Ha})$. Globally major onion producing countries are China, India, Egypt, USA, Iran, Turky, Russion Fedretion, Pakistan and Brazil. Out of these countries India has the maximum area under onion cultivation i.e. 1.20 million ha and Algeria has the minimum area under cultivation i.e. 0.05 milllon ha. But in production China has the maximum production in the world i.e. 23.91 million tons followed by India and Egypt. In terms of productivity USA has the highest productivity i.e. 56.40 ton/ Ha followed by Egypt and Iran. But the lowest productivity is in Pakistan i.e. $12.80 \mathrm{t} / \mathrm{ha}$. (Source: Horticultural statistics at glance 2018)

In the year 2018-19 India's total area under onion cultivation was 1267 (thousand ha), total production 23284 (thousand MT) and productivity was $18.3(\mathrm{MT} / \mathrm{Ha})$. In India major onion producing states are Maharashtra, Karnataka, Madhya Pradesh, Rajasthan, Bihar, Andhra Pradesh etc. Out of these states Maharashtra has maximum area under cultivation i.e. 507.96 (thousand ha) followed by Karnataka, Madhya Pradesh and Rajasthan. But in production Maharashtra has highest production i.e. 8854.09 MT followed by Madhya Pradesh, Karnatka and Bihar. Productivity is highest in Madhya Pradesh i.e. $24.53 \mathrm{t} / \mathrm{ha}$ followed by Haryana, Bihar and Andhra Pradesh. (Sourcewww.indiaagristat.com)

\section{Objective}

To study the growth and instability in area, production and yield of Onion in India.

\section{Materials and Methods}

For the present study Onion crop were selected because of its large area under production. The data related to area, production and productivity of onion were collected for the period 1995-96 to 2018-19 from www.indiaagristat.com websites. To estimate the growth and instability in area, production and yield various analytical tools were used. Compound growth rate and Cuddy-Della Valle Instability Index was used to estimate growth and instability in area, production and yield.

\section{Growth rate}

The compound growth rate was computed based on its fit using non-linear models, especially, the exponential model conventionally, the compound growth rates were estimated after converting the growth model to semi-log form and estimated through Ordinary Least Square (OLS) technique assuming multiplicative error term. However, there are several problems associated with this technique including the difficulty in estimating standard error of estimates of original parameters. Hence, a non-linear estimation technique for solving exponential model assuming additive error terms was used to estimate the compound growth rates.

$\mathrm{Yt}=\mathrm{constant}^{*}(1+\mathrm{CGR})+\epsilon_{\mathrm{t}}$

Where,

$\mathrm{Yt}$ is the time series data for area/production/yield for years $t$ 
$\mathrm{T}$ is the time trends for years of interest,

$€ t$ is the error term and

CGR is compound growth rate for the period under consideration.

The Marquardt algorithum was used to estimate the parameters of equation. The data were smoothened by taking three year moving average to remove bias if any, induced by the outliers. The significance of regression coefficients was tested by applying standard ' $t$ ' test procedure.

\section{Instability Index: Cuddy-Della Valle Index}

Cuddy-Della Valle Instability Index was used to estimate the instability in area, production, yield. This index is a modification of coefficient of variation (CV) to accommodate for trend, which is commonly present in time series economic data. It is superior over other scale dependent measures such as Standard Deviation or Root Mean Square of the residuals (RMSE) obtained from the fitted trend lines of the raw data and hence suitable for cross comparisons. The cuddy Della Index (IX) is calculated as follows.

$$
\mathbf{I x}=\mathbf{C V}^{\sqrt{(1-R)^{2}}}
$$

Where,

$\mathrm{CV}=$ Coefficient of Variation $\left(\delta / \mathrm{x}^{-}\right)$

$R^{2}=$ Adjusted coefficient of multiple determination

Where ever trend in the time series data in non significant, instability of that particular series was analyzed with the help of conventional statistical tool of instability i.e. coefficient of variation. The coefficient of variation $(\mathrm{CV})$ was calculated by using formula,
C V. $($ per cent $)=\frac{\text { Standard Deviation(a) }}{\text { Mean }} \times 100$

\section{Results and Discussion}

\section{Growth in Area, Production and Yield of onion in India}

The descriptive statistics of the area, production and yield of onion were calculated and presented in table 1. The data were analyzed by using various statistical tools. The average area under onion cultivation was 792.83 thousand ha, the average production was 11786.20 thousand MT and average yield was $13.68 \mathrm{MT} / \mathrm{Ha}$. The median is the middle value in the list of numbers. The median of area, production and yield were 762.05, 11503.10 and 14.15 respectively. The maximum value for area was 1320 thousand ha, production 23284 thousand MT and yield 18.30 MT/ Ha. The minimum value for area was 340 thousand ha, production 3140 thousand MT and for yield 9.20 MT/Ha. The standard deviation of area, production and yield were 349.10, 7139.03 and 3.07. Skewness is usually described as a measure of a dataset's symmetry - or lack of symmetry. A perfectly symmetrical data set will have a skewness of 0 . The skewness of area, production and yield were $0.26,0.29$ and 0.07 . Kurtosis of area was 1.49 , production and yield were 1.57 and 1.44, respectively. The Jarque- Bera of area production and yield were 2.56, 2.39 and 2.44. The Jarque-Bera statistics shows that, area, production and yield data of onion was not normally distributed.

The growth in area, production and yield of onion was estimated by using compound growth rates as described in methodology. The compound growth rate of area, production and yield of onion during period from 1995-96 to 2017-18 were calculated and presented in the table 2 . 
Mean, compound growth rate, standard error and ' $t$ ' value were given for area, production and productivity of onion in India. Average area under onion cultivation in India during the study period was 792.83 thousand ha, average production was 11786.20 thousand MT and average yield obtained was 13.68 MT/Ha. Compound growth rate for area was 6.15 percent, 8.58 percent for production and 2.92 percent for yield which recorded statistically significant and positive. Standard error value for area, production and productivity of onion is $0.42,0.58$ and 0.28 respectively. $\mathrm{T}$ value for area, production and productivity were $14.34,14.56$ and 10.11 respectively. The compound growth rate of production of onion was highest followed by area and yield. This clearly shows that the production of onion in the country was increased mainly due to area expansion followed by yield improvement. The CGR of area, production and yield of onion was statistically significant. The results of the study were in line with Choubey (2014) and Suvagiya et al., (2017) (Table 3).

Table.1 Descriptive statistics of area, production and yield of onion in India

\begin{tabular}{|l|c|c|c|}
\hline Descriptive Stat & Area & Production & Yield \\
\hline Mean & 792.83 & 11786.20 & 13.68 \\
\hline Median & 762.05 & 11503.10 & 14.15 \\
\hline Maximum & 1320.00 & 23284.00 & 18.30 \\
\hline Minimum & 340.00 & 3140.00 & 9.20 \\
\hline Std. Dev. & 349.10 & 7139.03 & 3.07 \\
\hline Skewness & 0.26 & 0.29 & -0.07 \\
\hline Kurtosis & 1.49 & 1.57 & 1.44 \\
\hline Jarque-Bera & 2.56 & 2.39 & 2.44 \\
\hline Probability & 0.28 & 0.30 & 0.29 \\
\hline Observations & 24.00 & 24.00 & 24.00 \\
\hline
\end{tabular}

Note area in “ 000 ”'ha, production in ' 000 'MT and yield in MT/Ha.

Table. 2 Growth in area, production and yield of onion in India

\begin{tabular}{|c|c|c|c|}
\hline Particulars & Area & Production & Yield \\
\hline Mean & 792.83 & 11786.20 & 13.68 \\
\hline CGR & 6.15 & 8.58 & 2.92 \\
\hline SE & 0.42 & 0.58 & 0.28 \\
\hline "t' Value & 14.34 & 14.56 & 10.11 \\
\hline
\end{tabular}

Area in “000”ha; Production in '000'MT and Yield in MT/Ha.

Table.3 Instability in area, production and yield of onion in India

\begin{tabular}{|l|c|c|c|}
\hline Particulars & Area & Production & Yield \\
\hline CV & 0.44 & 0.60 & 0.22 \\
\hline CDI & 0.13 & 0.16 & 0.09 \\
\hline
\end{tabular}


Fig.1 Time sequence plot of area, production and yield of onion in India

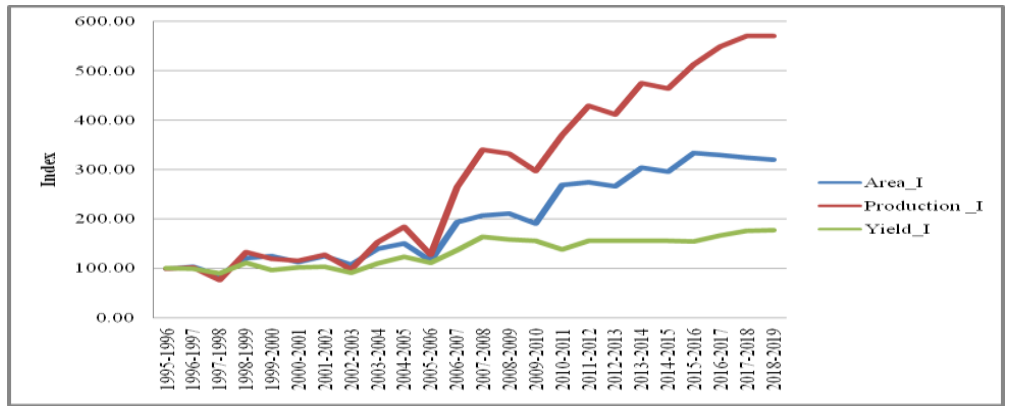

Fig.2 Time sequence plot of area of onion in India

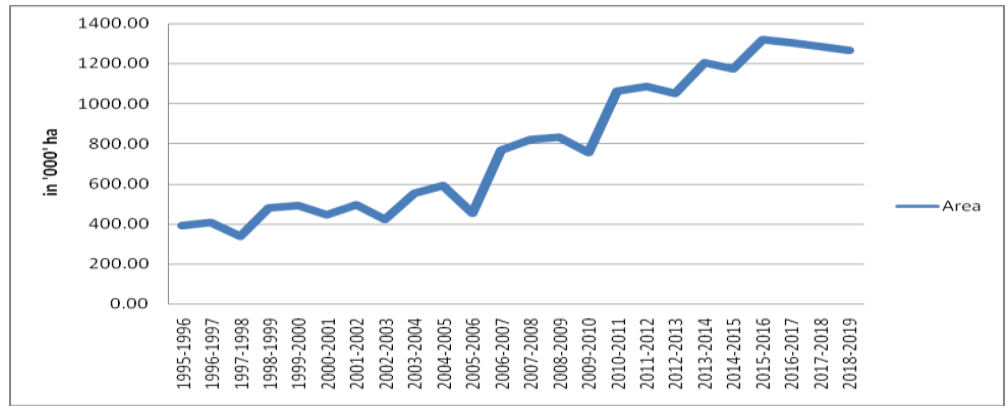

Fig.3 Time sequence plot of production of onion in India

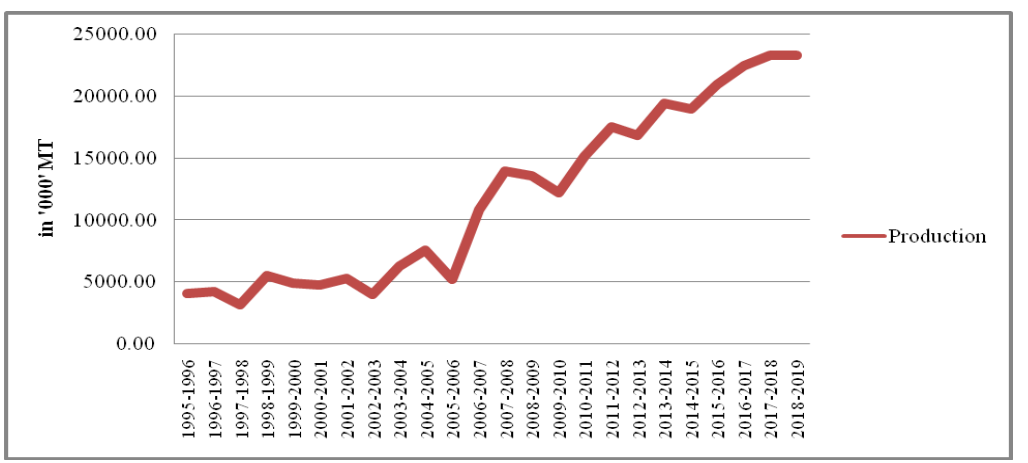

Fig.4 Time sequence plot of yield of onion in India

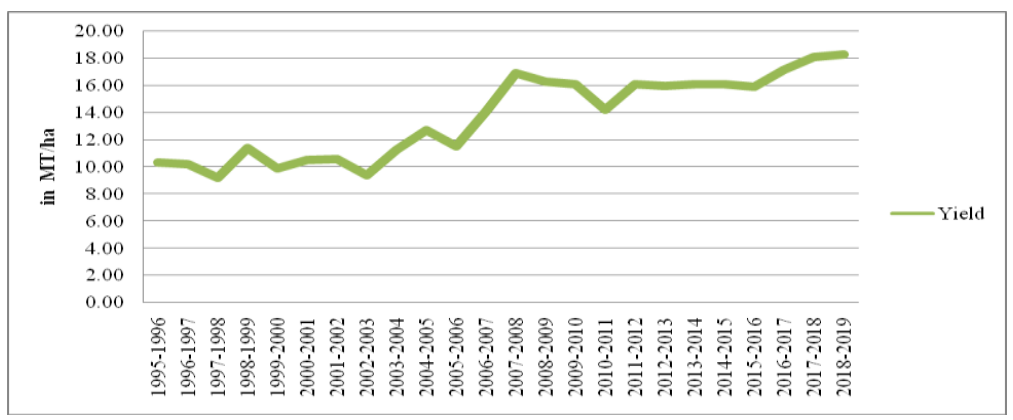


Figure 1 shows the growth in area, production and productivity of onion in India during the period 1995-96 to 2017-18. The graph indicates that there are lots of fluctuations in area, production and yield. From the period 1995-96 area of onion cultivation has uptrend and fluctuations area has increased up to the period 2018-19. Production line shows the lots fluctuations from period 1995-96 to 2005-06 after that productions increases rapidly up to the period 2018-19. Production has more volatility as compared to area and productivity. The third line indicates yield of onion per hector. The graph shows that yield has less fluctuations as compared to area and production which shows regular pattern of increase and decrease in yield. The graph shows that the productivity of onion lies in between 10 to 18 tons per ha.

Figure 2 indicates that, growth in area of onion significantly increased over the past 21 years i.e. (1995- 2016). It can also be seen that, the graph is not a smooth line but has lots of fluctuations indicating that area of onion is not steady year over year but sometimes increases and decreases. In this graph line indicates the growth in area in unstable due the diversification of agricultural field crops.

Figure 3 indicates the, growth in production of onion during the period 1995-96 to 201819. The line shows that, there are a large number of fluctuations in production of onion. During period 1995 to 2006 the moderate type of fluctuations are observed in the production. During the period 2007 to 2019, the production of onion increases continuously due to the proper utilization of fertilizers, awareness about the pesticides, use of new improved variety etc.

Figure 4 indicates the growth in yield of onion during the period 1995-96 to 2018-19. The line shows that, there is large number of fluctuations in yield of onion. During period 1995 to 2019 the yield of onion lies in between 10 to $18 \mathrm{MT} /$ ha.

The increase or decrease in yield is mainly due to the rainfall and other climatic condition.

The release of new varieties and innovative cultural practices developed in recent years were also responsible for the variations in yield. The highest yield was observed in year of 2018-19 and lowest yield was observed in the year of $2002-03$.

\section{Instability in area, production and yield of onion in India}

Estimate of instability in area, production and yield of onion in India was calculated with the help coefficient of variation and Cuddy Della Valle Index. Instability will explain the irregular fluctuations in area, production and yield during the study period.

To estimate the instability in area, production and yield of onion the Cuddy- Della Valle instability index was used. Coefficient of Variation of onion area was found to be 0.44 per cent and Cuddy- Della Valle instability Index was 0.13 per cent.

Coefficient of variation of onion production and yield was 0.60 per cent and 0.22 per cent respectively. Cuddy- Della Valle instability index for production and yield was 0.16 per cent and 0.09 per cent respectively. The results of the study were in line with Kale et al. (2016) and Kumar et al., (2019).

From the above results it is concluded that, compound growth rate of area, production and yield of Onion were statistically significant and positive. The highest instability was observed in production of onion followed by area and yield. 


\section{References}

Boyal, V.K., Pant, D.C., Burark, S.S. and J. Mehra (2015) Growth and instability in area, production and productivity of fenugreek in Rajasthan. International $J$. Seed Spices Vol. 5(1): 18-23.

Choubey, M., (2014) Production and Export of Onion: Time Series Analysis. Adarsh Journal of Management Research, Vol. $7(2)$ :

Horticultural statistics at glance 2018 www.indiaagristat.com

Kale, N.K., Sale, Y.C. and S.S. Bhosale (2016) Trends in area, production and productivity of onion in Maharashtra.
International Journal of Current Science and Technology, Vol. 4(9): 260-265.

Kumar, S., Singh, P.K., Rathi, D., Nahatkar, S.B., Choudhary, V.K. and S.K. Parey(2019) Growth and Instability in Area, Production and Productivity of Soyabean in India. International Journal of Science, Environment, Vol. 8(2): $278-288$.

Suvagiya, D., Shilpa, V.C., Shah P. and N.J. Ardeshna (2017) Growth Performance of Major Vegetable Crops in Gujarat State. Agricultural Economics Research Review, Vol. 30(1): 139-149.

\section{How to cite this article:}

Nalegaonkar, A. R., S. S. More, R. D. Shelke and Gade, P. A. 2020. Growth and Instability in Area, Production and Yield of Onion in India. Int.J.Curr.Microbiol.App.Sci. 9(11): 2761-2767. doi: https://doi.org/10.20546/ijcmas.2020.911.335 